Article

\title{
Ethanol Induces Microglial Cell Death via the NOX/ROS/PARP/TRPM2 Signalling Pathway
}

\author{
Muhammad Syahreel Azhad Sha'fie ${ }^{1}{ }^{10}$, Sharani Rathakrishnan ${ }^{1}$, Iffa Nadhira Hazanol ${ }^{1}$, \\ Mohd Haziq Izzazuddin Dali ${ }^{1}$, Mohd Ezuan Khayat ${ }^{1}{ }^{\circledR}$, Syahida Ahmad ${ }^{1}$, Yazmin Hussin ${ }^{2}(0)$ \\ Noorjahan Banu Alitheen ${ }^{2}$, Lin-Hua Jiang $3,4, *$ (i) and Sharifah Alawieyah Syed Mortadza $1,4, *$ (D) \\ 1 Department of Biochemistry, Faculty of Biotechnology and Biomolecular Sciences, Universiti Putra Malaysia, \\ Serdang 43400, Selangor, Malaysia; 188825@student.upm.edu.my (M.S.A.S.); \\ gs57745@student.upm.edu.my (S.R.); 190382@student.upm.edu.my (I.N.H.); \\ 189944@student.upm.edu.my (M.H.I.D.); m_ezuan@upm.edu.my (M.E.K.); syahida@upm.edu.my (S.A.) \\ 2 Department of Cell and Molecular Biology, Faculty of Biotechnology and Biomolecular Sciences, \\ Universiti Putra Malaysia, Serdang 43400, Selangor, Malaysia; yazminh93@gmail.com (Y.H.); \\ noorjahan@upm.edu.my (N.B.A.) \\ 3 Sino-UK Joint Laboratory of Brain Function and Injury of Henan Province and Department of Physiology \\ and Pathophysiology, Xinxiang Medical University, Xinxiang 453003, China \\ 4 School of Biomedical Sciences, Faculty of Biological Sciences, University of Leeds, Leeds LS2 9JT, UK \\ * Correspondence: 1.h.jiang@leeds.ac.uk (L.-H.J.); s_alawieyah@upm.edu.my (S.A.S.M.); \\ Tel.: +44-113-3434231 (L.-H.J.); +60-11-11483805 (S.A.S.M.)
}

Received: 12 October 2020; Accepted: 7 December 2020; Published: 9 December 2020

check for updates

\begin{abstract}
Microglial cells are the primary immune cell resident in the brain. Growing evidence indicates that microglial cells play a prominent role in alcohol-induced brain pathologies. However, alcohol-induced effects on microglial cells and the underlying mechanisms are not fully understood, and evidence exists to support generation of oxidative stress due to NADPH oxidases (NOX_-mediated production of reactive oxygen species (ROS). Here, we investigated the role of the oxidative stress-sensitive $\mathrm{Ca}^{2+}$-permeable transient receptor potential melastatin-related 2 (TRPM2) channel in ethanol (EtOH)-induced microglial cell death using BV2 microglial cells. Like $\mathrm{H}_{2} \mathrm{O}_{2}$, exposure to $\mathrm{EtOH}$ induced concentration-dependent cell death, assessed using a propidium iodide assay. $\mathrm{H}_{2} \mathrm{O}_{2} / \mathrm{EtOH}$-induced cell death was inhibited by treatment with TRPM2 channel inhibitors and also treatment with poly(ADP-ribose) polymerase (PARP) inhibitors, demonstrating the critical role of PARP and the TRPM2 channel in EtOH-induced cell death. Exposure to EtOH, as expected, led to an increase in ROS production, shown using imaging of $2^{\prime}, 7^{\prime}$-dichlorofluorescein fluorescence. Consistently, EtOH-induced microglial cell death was suppressed by inhibition of NADPH oxidase (NOX) as well as inhibition of protein kinase C. Taken together, our results suggest that exposure to high doses of ethanol can induce microglial cell death via the NOX/ROS/PARP/TRPM2 signaling pathway, providing novel and potentially important insights into alcohol-induced brain pathologies.
\end{abstract}

Keywords: alcoholism; microglia; cell death; ROS; oxidative stress; PARP; TRPM2; NOX

\section{Introduction}

Alcoholism represents a major cause of morbidity and mortality worldwide, as reported by the National Institute of Alcohol Abuse and Alcoholism, as part of the US National Institutes of Health [1]. Excessive alcohol consumption has numerous detrimental effects on many parts of the human body, leading to liver diseases, heart diseases, and neuropathologies such as alcohol use disorder, a severe and relapsing mental health disease due to alcohol-induced alterations of brain functions [1-7]. In addition, as has been well documented, alcohol intake causes the brain to promote 
further alcohol consumption [7]. Regarding how alcohol impacts the brain, multiple molecular and cellular mechanisms have been proposed, including increased poly(ADP-ribose) polymerase (PARP) activity and ensuing regulation of gene expression, induction of oxidative stress via NADPH oxidases (NOX)-mediated generation of reactive oxygen species (ROS), neurotoxicity, neuromodulation, and neuroinflammation [7-12].

Microglial cells are the privileged immune cells in the central nervous system (CNS) and they play a central role in innate immune signaling and are vital for the surveillance and maintenance of the homeostasis in the CNS [13-15]. However, it is well recognized that chronic or dysregulated microglial activation can cause excessive generation of proinflammatory cytotoxic mediators, including ROS [13-15]. Microglial cells are known to be activated by structurally diverse molecules, including ethanol (EtOH). Increasing attention has been devoted to understanding the role of microglial cells in alcohol-induced signaling, and compelling evidence has been gathered to support the conclusion that microglial cell-mediated inflammatory responses are important in mediating alcohol-induced toxicity in both fetal and adult brains [7,11,16-24]. More specifically, several molecular mechanisms have been identified in alcohol-induced microglial cell-mediated neuroinflammation, including NOX, which mediates ROS generation, and ATP-sensitive P2X7 receptor, which is crucially involved in the generation of proinflammatory cytokines and neuroinflammation [11,24]. It is well recognized that exposure to high amounts of alcohol can cause neuronal cell death, which is critical in contributing to alcohol-related brain damage, but the effect of alcohol on microglial cell viability is unknown $[11,12,18]$. However, there is increasing evidence to show microglial cells' demise in response to oxidative stress induced by exposure to ROS or ROS-inducing pathological factors $[25,26]$.

Transient receptor potential melastatin-related 2 (TRPM2) is a $\mathrm{Ca}^{2+}$-permeable cationic channel gated by intracellular ADP-ribose (ADPR) [27]. The TRPM2 channel is highly sensitive to activation by high levels of ROS or oxidative stress, as a result of ADPR generation via engaging poly(ADPR) polymerases (PARP), particularly PARP-1, in the nucleus [27]. Now, there is a large volume of experimental evidence to support the TRPM2 channel as one of the critical molecular mechanisms for oxidative stress-related pathologies [28,29]. The TRPM2 channel is known to be highly expressed in microglial cells [25,26,30-33]. Recent studies from our group and other authors using pharmacological and/or genetic interventions have shown an important role for the TRPM2 channel in signaling mechanisms mediating the responses of microglial cells, including cell death, to ROS and pathological factors, such as amyloid $\beta$-peptide, $\mathrm{MPP}^{+}$, and $\mathrm{Zn}^{2+}$, which are known to be able to stimulate ROS generation $[25,26,31]$. In this study, we are interested in whether alcohol-induced oxidative stress results in microglial cell death and, if this is true, whether and how the TRPM2 channel is involved in such alcohol-induced cell death, using murine BV2 microglial cells, a widely-used cell model for in vitro studies of microglial cell-mediated mechanisms, including those induced by ethanol $[34,35]$. We show that exposure to high doses of $\mathrm{EtOH}$ induces microglial cell death and provide evidence to show that EtOH causes microglial cell death via induction of NOX-mediated ROS generation and subsequent activation of PARP and the TRPM2 channel. Our findings have led us to propose a novel mechanism that is potentially critical in mediating alcohol-induced brain pathologies.

\section{Materials and Methods}

\subsection{Chemicals and Reagents}

All chemicals or reagents were commercially obtained from Sigma-Aldrich unless specified otherwise. PJ34 was from Santa Cruz, GKT137831 from Cayman Chemical, and chelerythrine chloride (CTC) from Tocris.

\subsection{BV2 Cell Culture and Preparation}

BV2 cells, a mouse microglia cell line ICLCATL03001 originally from Cell Line Collection Banca Biologica e Cell Factory, were maintained in Dulbecco's modified Eagle medium (DMEM) containing 
$25 \mathrm{mM}$ glucose, supplemented with $10 \%$ heat-inactivated fetal bovine serum (FBS) and maintained in a tissue culture incubator at $37{ }^{\circ} \mathrm{C}$ under $5 \% \mathrm{CO}_{2}$ humidified conditions. Cells were cultured in $25-\mathrm{cm}^{2}$ flasks and passaged when cells reached $>80 \%$ confluence. Cells were detached from the bottoms of flasks using $0.05 \%$ trypsin-EDTA (Invitrogen), collected by centrifugation, re-suspended in fresh culture media, and sub-cultured in $25-\mathrm{cm}^{2}$ flasks or in 96-well plates for experimentation.

\subsection{Reverse Transcription-Polymerase Chain Reaction (RT-PCR)}

Total RNA was isolated using the TRIZOL reagent (Invitrogen) and dissolved into RNase-free water, and first-strand cDNA was synthesized using SuperScript II reverse transcriptase (Invitrogen) according to the manufacturer's instructions. PCR was conducted in $20 \mu \mathrm{L}$ using Mastercycler 5333 (Eppendorf, Hamburg, Germany) and Taq DNA polymerase (New England BioLabs). The forward and reverse primer sequences are $5^{\prime}$-AAGCCTAAGTGTCCTGAGAGCG and 5'-ATGTCCAGCAGATCCACCATGG, with the PCR product having a size of $479 \mathrm{bp}$. The PCR conditions used were as follows: initial denaturation at $95^{\circ} \mathrm{C}$ for $2 \mathrm{~min}$ followed by 35 cycles of $95^{\circ} \mathrm{C}$ for $30 \mathrm{~s}, 59^{\circ} \mathrm{C}$ for $60 \mathrm{~s}$, and $72{ }^{\circ} \mathrm{C}$ for $30 \mathrm{~s}$. The PCR products were resolved in $2 \%$ agarose gels and documented using a Gel Imaging and Quantity One (Biorad).

\subsection{Immunofluorescent Staining}

Cells were seeded on 13-mm glass coverslips 12-24 h before use. Cells were rinsed with phosphate buffer saline (PBS: $8 \mathrm{~g} / \mathrm{L} \mathrm{NaCl}, 0.2 \mathrm{~g} / \mathrm{L} \mathrm{KCl}, 1.44 \mathrm{~g} / \mathrm{L} \mathrm{Na} 2 \mathrm{PO}_{4}$, and $0.24 \mathrm{~g} / \mathrm{L} \mathrm{KH}_{2} \mathrm{PO}_{4}$ in water, $\mathrm{pH}$ 7.4) and fixed using methanol for $5 \mathrm{~min}$ at $-20{ }^{\circ} \mathrm{C}$. After washing with PBS containing $0.4 \%$ (v:v) Trition X-100 (PBS-T), cells were incubated in the blocking solution (PBS with 10\% (w:v) bovine serum albumin) at room temperature for $30 \mathrm{~min}$. Cells were incubated with the primary rabbit anti-TRPM2 antibody (Bethyl) at a dilution of 1:800 at $4{ }^{\circ} \mathrm{C}$ overnight. After washing with PBS-T, cells were incubated with the secondary fluorescein isothiocyanate-conjugated anti-rabbit IgG antibody (Sigma) at 1:500 for $1 \mathrm{~h}$ at room temperature. After washing with PBS-T, coverslips were dried on tissue papers and mounted inversely on glass slides with anti-fade fluorescent mounting medium containing 4',6-diamidino-2-phenylindole (DAPI) (Molecular Probes). Cells stained with only the secondary antibody were used as a negative control. Fluorescent images were captured using a LSM510 META confocal microscope and analyzed using LSM Image (Zeiss, Jena, Germany).

\subsection{Single-Cell $\mathrm{Ca}^{2+}$ Imaging}

Single-cell $\mathrm{Ca}^{2+}$ imaging was performed at room temperature as described in our previous study [36]. In brief, cells were seeded on 13-mm glass coverslips $12-24 \mathrm{~h}$ before use. Cells were incubated for $1 \mathrm{~h}$ with $4 \mu \mathrm{M}$ Fura-2 AM (Molecular Probes) in extracellular $\mathrm{Ca}^{2+}$-containing solution $\left(134 \mathrm{mM} \mathrm{NaCl}, 5 \mathrm{mM} \mathrm{KCl}, 1.2 \mathrm{mM} \mathrm{MgCl}, 1.5 \mathrm{mM} \mathrm{CaCl}_{2}, 8 \mathrm{mM}\right.$ glucose, and $10 \mathrm{mM}$ HEPES, $\mathrm{pH}$ 7.4) or extracellular $\mathrm{Ca}^{2+}$-free solution containing $5 \mathrm{mM} \mathrm{EGTA}$ and no $\mathrm{CaCl}_{2}$. Intracellular $\mathrm{Ca}^{2+}$ concentrations in individual cells were determined by the ratio of F340/F380, the fluorescence intensities that excited alternatively at 340 and $380 \mathrm{~nm}$, emitted at $510 \mathrm{~nm}$, and captured using an Axiovert S100TV microscope (Zeiss) and Openlab 2 software (Image Processing and Vision, Agilent, Santa Clara, CA, USA). Extracellular solutions alone or containing $300 \mu \mathrm{M} \mathrm{H}_{2} \mathrm{O}_{2}$ were applied to cells by a gravity-fed perfusion system after establishment of the baseline. In some experiments, cells were initially exposed to $\mathrm{H}_{2} \mathrm{O}_{2}$ in a Ca ${ }^{2+}$-free solution and then in $\mathrm{Ca}^{2+}$-containing solutions. $\mathrm{F} 340 / \mathrm{F} 380$ values in each cell were normalized to the basal value at the time of starting $\mathrm{H}_{2} \mathrm{O}_{2}$ application.

\subsection{Cell Death Assay}

Cells were seeded in a 96-well plate at a concentration of $7 \times 10^{3}$ cells $/ \mathrm{mL}$ and incubated overnight at $37^{\circ} \mathrm{C}$ before use. Cells were treated with indicated concentrations of $\mathrm{H}_{2} \mathrm{O}_{2}$ or EtOH at $37^{\circ} \mathrm{C}$ for $24 \mathrm{~h}$, in the majority of experiments, or $\mathrm{EtOH}$ for $8 \mathrm{~h}$, in a small number of experiments, as specifically 
indicated in figure legends. After treatment with $\mathrm{H}_{2} \mathrm{O}_{2}$ or EtOH, cells were incubated with $2 \mu \mathrm{g} / \mathrm{mL}$ propidium iodide (PI) at $37^{\circ} \mathrm{C}$ for a further $30 \mathrm{~min}$ prior to imaging. Cells were co-stained with $5 \mu \mathrm{g} / \mathrm{mL}$ Hoechst 33342 (Hoechst) or $1 \mu \mathrm{g} / \mathrm{mL}$ acridine orange (AO). Cells were imaged using a fluorescent microscope equipped with a camera (Nikon). The number of PI-positive dead cells and the total number of cells identified by co-staining with Hoechst or $\mathrm{AO}$ in three randomly-chosen areas in each image were counted using ImageJ, and at least 80 cells were examined in each well. Cell death was presented by expressing PI-positive cells as a percentage of all cells identified in the same areas.

\subsection{Measurement of ROS Production}

Intracellular ROS production was assessed using $2^{\prime}, 7^{\prime}$-dichlorodihydrofluorescein diacetate (DCFH-DA) (Sigma) by measuring the $2^{\prime}, 7^{\prime}$-dichlorofluorescein (DCF) fluorescence intensity, as described in our previous study [31]. Briefly, cells plated in 96-well plates were treated with EtOH at indicated concentrations for $8 \mathrm{~h}$. Cells were washed with PBS before being loaded with $20 \mu \mathrm{M}$ DCFH-DA in PBS at $37^{\circ} \mathrm{C}$ for $20 \mathrm{~min}$. Cells were washed with PBS prior to imaging. Images were captured using a fluorescent microscope (Nikon) and NIS-Elements Viewer software. The DCF fluorescent intensity in each cell was quantified using ImageJ and at least 75 cells were examined in each well.

\subsection{Data Presentation and Statistical Analysis}

All data are presented as mean \pm standard error of mean, obtained from individual cells for single-cell calcium imaging or each independent cell preparation for cell death and ROS production. Statistical analysis was performed using the Student's $t$-test for comparisons of two groups and a one-way ANOVA followed by post hoc Tukey's test for comparison among multiple groups, with $p<0.05$ being statistically significant.

\section{Results}

\subsection{Expression of TRPM2 in Microglial Cells and Its Role in $\mathrm{H}_{2} \mathrm{O}_{2}$-Induced Cell Death}

We characterized TRPM2 channel expression in BV2 microglial cells using RT-PCR and immunofluorescent imaging. TRPM2 mRNA and protein expression was readily detected (Figure 1a,b). Of note, TRPM2 immunoreactivity was highly concentrated on or in the vicinity of the plasma membrane (Figure 1b). As shown using single-cell imaging, individual cells responded to exposure to $\mathrm{H}_{2} \mathrm{O}_{2}(300 \mu \mathrm{M})$, a widely used paradigm of inducing cellular oxidative stress, with a salient increase in intracellular $\mathrm{Ca}^{2+}$ concentration (Figure 1c). Furthermore, single-cell imaging using the $\mathrm{Ca}^{2+}$ add-back protocol revealed that such robust $\mathrm{Ca}^{2+}$ responses induced by exposure to $\mathrm{H}_{2} \mathrm{O}_{2}$ resulted from extracellular $\mathrm{Ca}^{2+}$ influx (Figure 1d). Taken gather, these data suggest that the TRPM2 channel mainly functions as a $\mathrm{Ca}^{2+}$-permeable channel on the cell surface, as reported in primary microglial cells [28-30]. We further examined whether prolonged exposure to ROS induced cell death via the TRPM2 channel. There were very few PI-positive dead cells under the control condition, but the percentage of PI-positive cells was significantly increased following exposure to $100-300 \mu \mathrm{M} \mathrm{H}_{2} \mathrm{O}_{2}$ (Figure 2a,b). Such cell death was significantly inhibited by treatment with 2-aminoethoxydiphenyl borate (2-APB), a known TRPM2 channel inhibitor (Figure 2c,d), or by treatment with PJ34 and 3,4-dihydro-5[4-(1-piperindinyl)butoxy]-1(2H)-isoquinoline (DPQ), two structurally different PARP inhibitors (Figure 2e-h). Thus, exposure to oxidative stress can induce PARP-dependent TRPM2 channel activation in BV2 microglial cells that can lead to cell death, highly consistent with our recent study examining primary microglial cells [25]. 
a

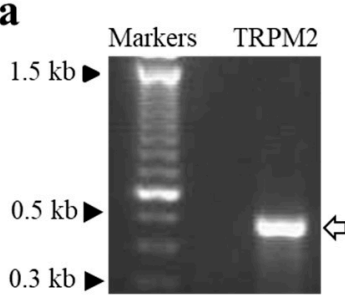

b
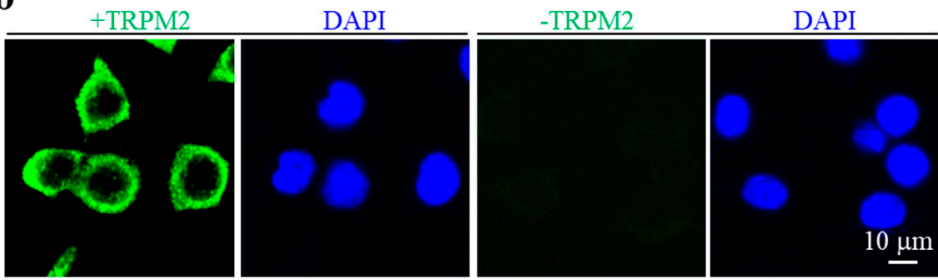

c
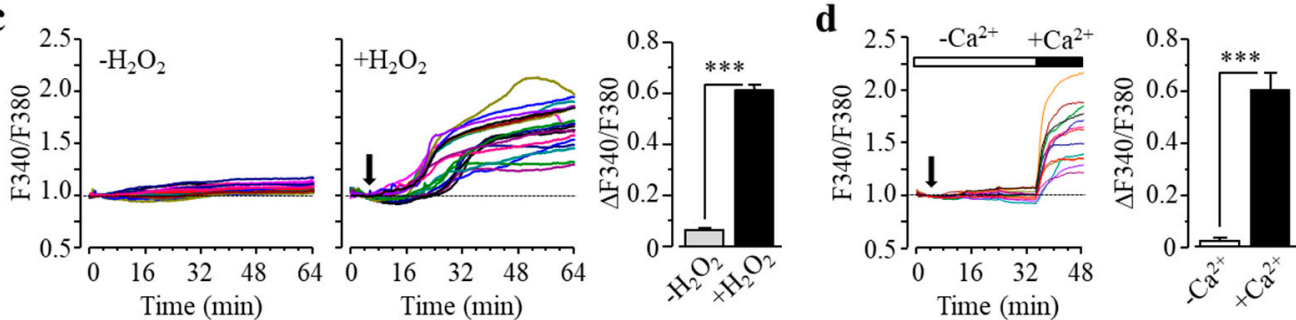

Figure 1. Transient receptor potential melastatin-related 2 (TRPM2) expression in BV2 microglial cells. (a) Agarose gel analysis showing TRPM2 mRNA expression (the arrow denotes the PCR product with the expected size of $479 \mathrm{bp}$ ). (b) Representative confocal images showing cells stained with the TRPM2 antibody and 4',6-diamidino-2-phenylindole (DAPI) (left) or stained only with the second antibody and DAPI (right). (c) Left: F340/F380 in individual cells without or with exposure to $300 \mu \mathrm{M}$ $\mathrm{H}_{2} \mathrm{O}_{2}$ (indicated by the downward arrow). Right: mean change in F340/F380 after 30 min exposure to $\mathrm{H}_{2} \mathrm{O}_{2}$ or equivalent time point (63 control cells and $78 \mathrm{H}_{2} \mathrm{O}_{2}$-exposued cells). (d) Left: F340/F380 in individual cells during exposure to $300 \mathrm{\mu M} \mathrm{H}_{2} \mathrm{O}_{2}$, firstly in extracellular $\mathrm{Ca}^{2+}$-free solution and then $\mathrm{Ca}^{2+}$-containing solution, indicated by the open and the solid bars above, respectively. Right: mean change in F340/F380 during exposure to $\mathrm{H}_{2} \mathrm{O}_{2}$ in $\mathrm{Ca}^{2+}$-free and $\mathrm{Ca}^{2+}$-containing solutions (14 cells). *** $p<0.005$ compared to indicated group.

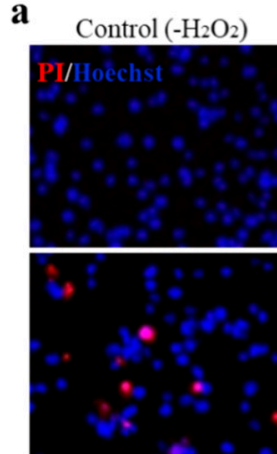

$100 \mu \mathrm{MH}_{2} \mathrm{O}_{2}$

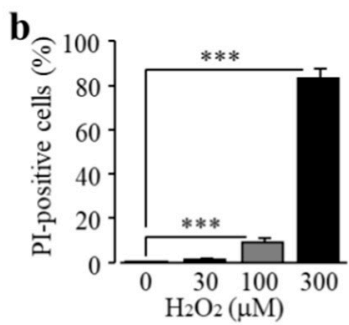

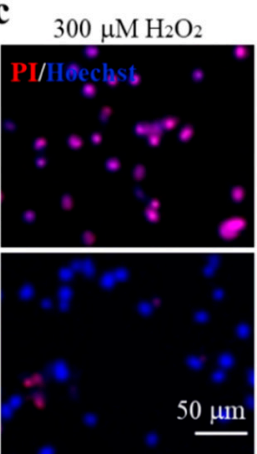

$+100 \mu \mathrm{M} 2-\mathrm{APB}$

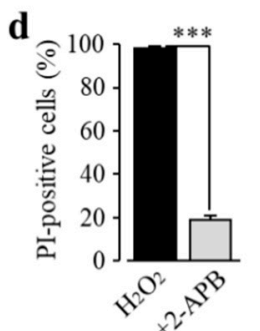

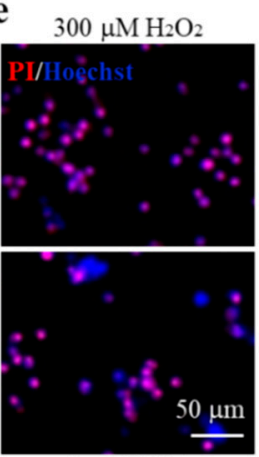

$+1 \mu \mathrm{M}$ PJ34

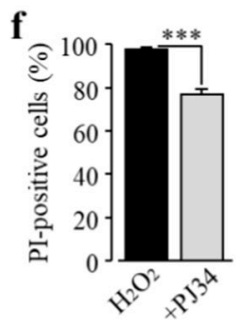

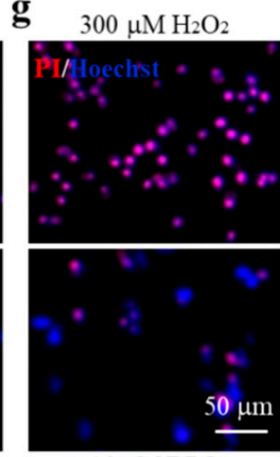

$+10 \mu \mathrm{MDPQ}$

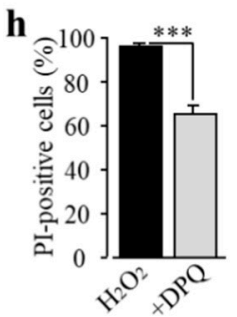

Figure 2. Reactive oxygen species (ROS) induce BV2 microglial cell death via poly(ADP-ribose) polymerase (PARP)-dependent TRPM2 channel activation. (a,b) Representative fluorescent images showing co-staining with propidium iodide (PI) and Hoechst (a) and mean percentage of PI-positive cells (b) in cells without (control) and with exposure to indicated concentrations of $\mathrm{H}_{2} \mathrm{O}_{2}$ for $24 \mathrm{~h}$. 
(c-h) Representative fluorescent images showing co-staining with PI and Hoechst in cells exposed to $300 \mathrm{\mu M} \mathrm{H}_{2} \mathrm{O}_{2}$ for $24 \mathrm{~h}$ without and with treatment with indicated inhibitors $(\mathbf{c}, \mathbf{e}, \mathbf{g})$ and mean percentage of PI-positive cells $(\mathbf{d}, \mathbf{f}, \mathbf{h})$. Cells were pre-treated with inhibitors $30 \mathrm{~min}$ prior to and during exposure to $\mathrm{H}_{2} \mathrm{O}_{2}$. Mean data are from at least three independent experiments, using three wells of cells for each condition in each experiment. ${ }^{* * *} p<0.005$ compared to indicated group.

\subsection{Exposure to EtOH Induces Microglial Cell Death via PARP-Dependent TRPM2 Channel Activation}

As introduced above, exposure to high doses of alcohol can induce ROS generation and oxidative stress, but it is unknown whether alcohol-induced oxidative stress can induce cell death in microglial cells. Therefore, we investigated the effects of exposure to EtOH for $24 \mathrm{~h}$ at concentrations $(10-300 \mathrm{mM})$ which have been commonly used for in vitro studies [34,35,37-39]. As shown in Figure 3a,b, exposure to EtOH induced concentration-dependent microglial cell death, with the cell death level significantly increased following exposure to high concentrations (100 and $300 \mathrm{mM}$ ). As shown above for $\mathrm{H}_{2} \mathrm{O}_{2}$-induced cell death, EtOH-induced cell death was also strongly attenuated by treatment with 2-APB and $\mathrm{N}$-(p-amylcinnamoyl)anthranilic acid (ACA), another TRPM2 channel inhibitor, or by treatment with PJ34 and DPQ (Figure 3c,d). These results are consistent with the notion that EtOH induces microglial cell death via PARP-dependent TRPM2 channel activation.

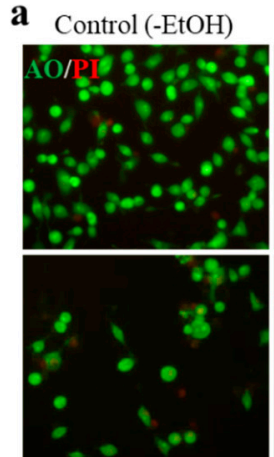

$100 \mathrm{mMEtOH}$

b

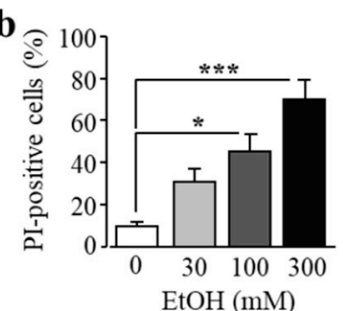

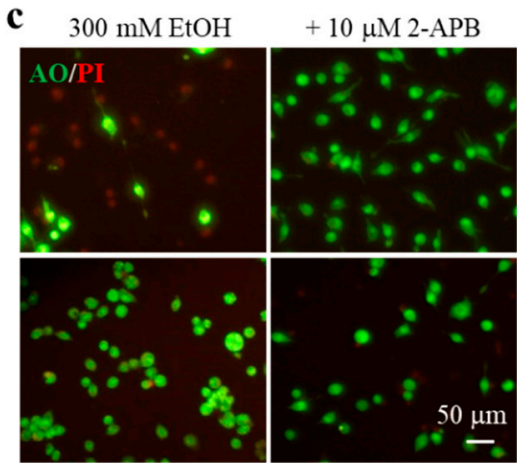

$+3 \mu \mathrm{M}$ PJ34

$+30 \mu \mathrm{M} \mathrm{DPQ}$

d

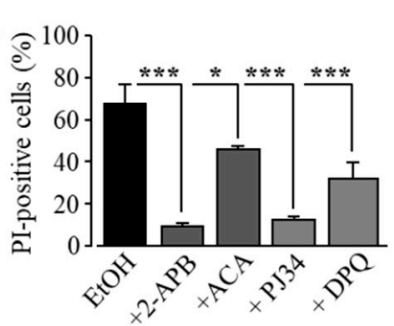

Figure 3. Ethanol (EtOH) induces BV2 microglial cell death via PARP-dependent TRPM2 channel activation. (a,b) Representative fluorescent images showing co-staining with PI and acridine orange (AO) (a) and mean percentage of PI-positive cells (b) in cells without (control) and with exposure to indicated concentrations of EtOH for $24 \mathrm{~h}$. (c,d) Representative fluorescent images showing co-staining with PI and AO in cells exposed to $300 \mathrm{mM} \mathrm{EtOH}$ for $24 \mathrm{~h}$ without and with treatment with indicated inhibitors (c) and mean percentage of PI-positive cells from three independent experiments, using three wells of cells for each condition in each experiment (d). Cells were pre-treated with inhibitors $30 \mathrm{~min}$ prior to and during exposure to EtOH. ${ }^{*} p<0.05 ;{ }^{* *} p<0.005$ compared to indicated control group.

\subsection{EtOH-Induced Microglial Cell Death Depends on NOX-Mediated ROS Generation}

It is known that exposure to alcohol induces ROS generation via NOX [11]. Previous studies by our group and other authors showed that activation of NOX is crucial in $\mathrm{Zn}^{2+}$-induced ROS production in neurons and microglial cells, with a dependency of protein kinase $C$ (PKC) in microglia $[25,31,40]$. Therefore we hypothesized that PKC and NOX play a similar role in EtOH-induced ROS production that induces subsequent activation of PARP and the TRPM2 channel, leading to microglial cell death. 
To address this, we firstly used single-cell imaging to measure the intensity of DCF, a fluorescent indicator for ROS generation, to investigate whether exposure to $\mathrm{EtOH}$ promoted ROS production in BV2 microglial cells. Exposure to $30-300 \mathrm{mM}$ EtOH induced a concentration-dependent increase in the cytosolic ROS level, with the level being significantly higher after exposure to 100 and $300 \mathrm{mM}$ (Figure 4a,b), consistent with the fact that NOX mediates alcohol-induced ROS generation. EtOH-induced microglial cell death was strongly attenuated by treatment with CTC, a PKC inhibitor (Figure 4c,d), and also by treatment with diphenyleneiodonium (DPI), a NOX generic inhibitor, and by treatment with GKT-137831, a NOX1/4-specific inhibitor (Figure 4e,f). Collectively, these data support a significant role of NOX-mediated ROS generation in ethanol-induced TRPM2 channel activation and cell death.

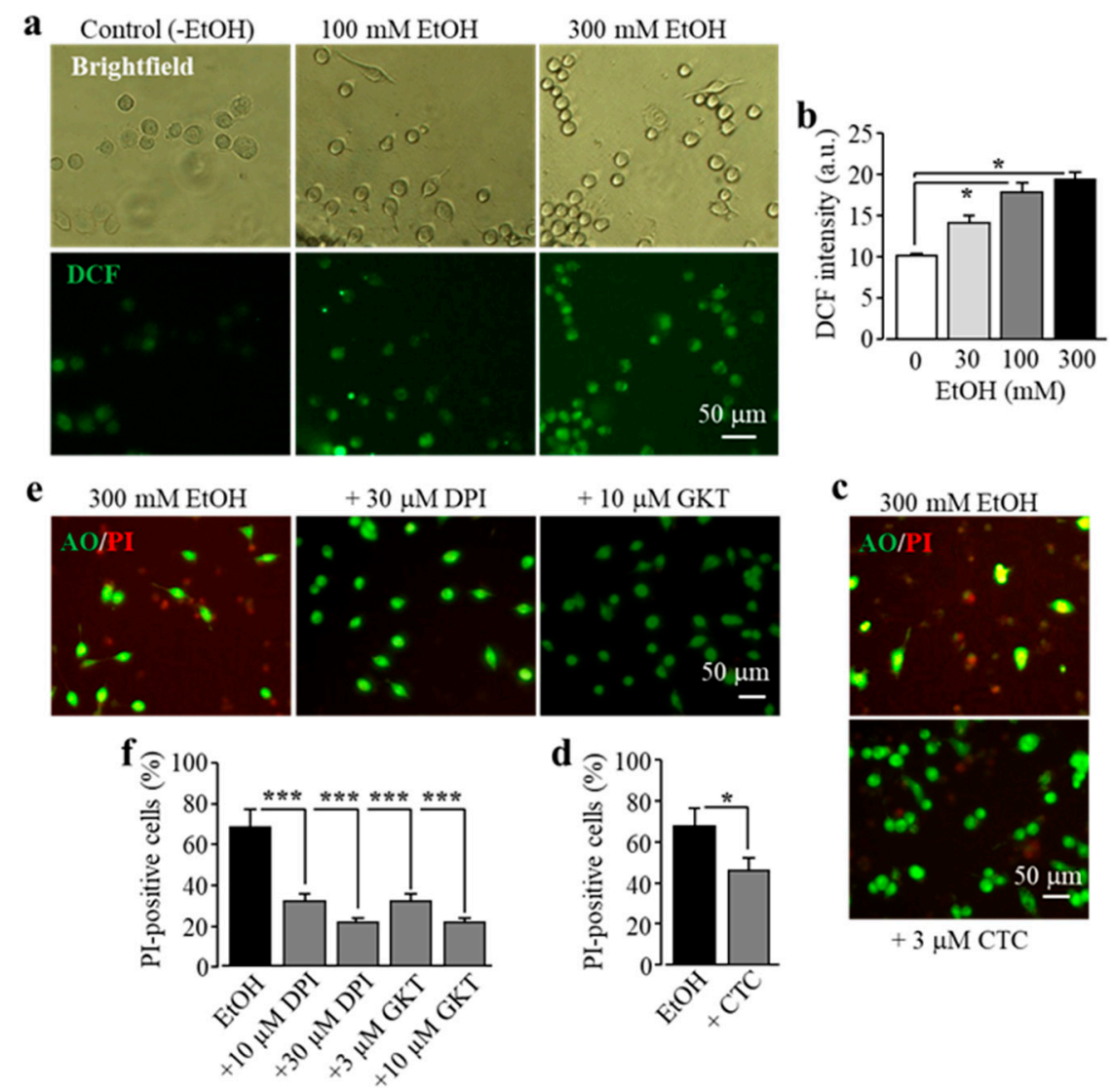

Figure 4. EtOH induces cell death in BV2 microglial cells via protein kinase C (PKC) and NOX-mediated ROS production. (a,b) Representative fluorescent images showing cellular ROS level (top row: brightfield in phase-contrast; bottom row: $2^{\prime}, 7^{\prime}$-dichlorofluorescein (DCF ) fluorescence) in microglial cells without (control) and with exposure to indicated concentrations of $\mathrm{EtOH}$ for $8 \mathrm{~h}$ (a), and mean DCF fluorescence intensity in microglial cells under indicated conditions from three independent experiments, using three wells of cells for each condition in each experiment. (c-f) Representative fluorescent images showing co-staining with PI and $\mathrm{AO}(\mathbf{c}, \mathbf{e})$ and mean percentage of PI-positive cells $(\mathbf{d}, \mathbf{f})$ in cells without (control) and with exposure to indicated concentrations of EtOH for $8 \mathrm{~h}$ alone or together with chelerythrine chloride (CTC), diphenyleneiodonium (DPI), or GKT -137831 (GKT). Cells were pre-treated with the inhibitors $30 \mathrm{~min}$ prior to and during exposure to EtOH. Mean data are from three independent experiments, using three wells of cells for each condition in each experiment. ${ }^{*} p<0.05 ;{ }^{* * *} p<0.005$ compared to indicated control group. 


\section{Discussion}

In the present study, we show that exposure to high concentrations of EtOH induced microglial cell death and provide evidence to suggest that EtOH-induced microglial cell death occurs via the NOX/ROS/PARP/TRPM2 signaling pathway (Figure 5).

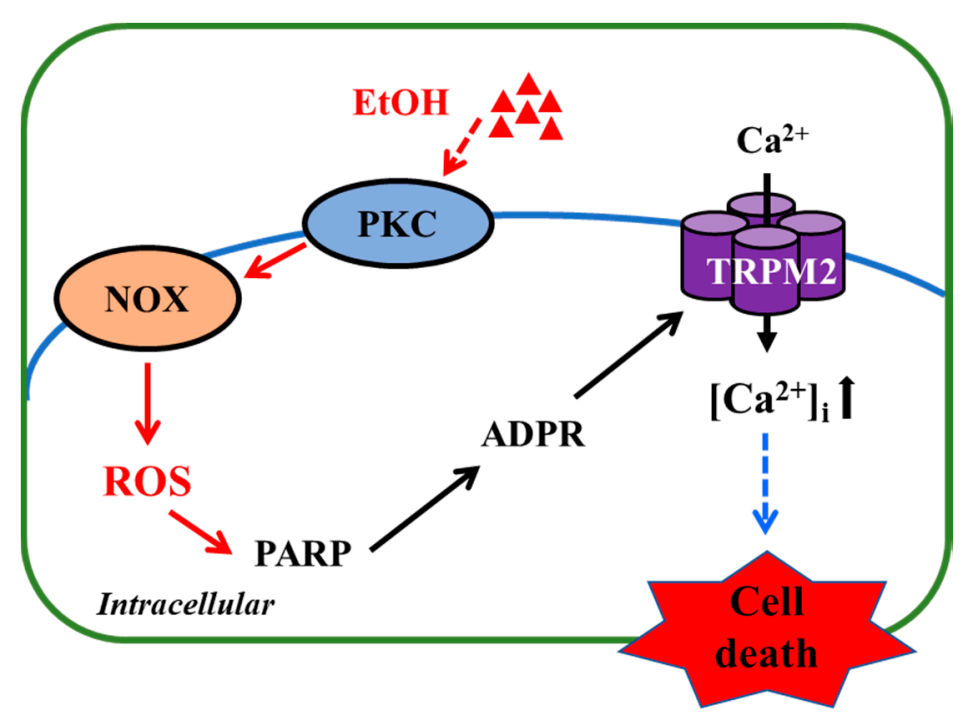

Figure 5. TRPM2-mediated signaling mechanism for EtOH-induced microglial cell death. Exposure to EtOH stimulates PKC and NOX to generate ROS, which, in turn, induce PARP-dependent ADP-ribose (ADPR) production and subsequent TRPM2 channel activation, leading to an increase in intracellular $\mathrm{Ca}^{2+}$ concentrations $\left(\left[\mathrm{Ca}^{2+}\right]_{i}\right)$ and cell death. Abbreviations: PKC, protein kinase $\mathrm{C}$; NOX, nicotinamide adenine dinucleotide phosphate oxidase; ROS, reactive oxygen species; PARP, poly (ADP-ribose) polymerase; ADPR, ADP-ribose.

It is well documented that excessive consumption of alcohol has extensive harmful effects on the brain among many other parts of the human body [1,6], and how exactly alcohol affects the brain remains a hot research topic. As introduced above, an increasing number of studies support a significant role of microglial cells in alcohol-induced brain pathologies [7,11,16-24]. However, the mechanisms driving the progression of microglial cell-associated alcohol pathologies still remain not fully understood. There is a large body of evidence suggesting a crucial role of the TRPM2 channel in cell death in diverse cell types, including microglial cells, induced by exposure to ROS or by pathological factors that are known to stimulate ROS generation [25-29,31,33]. However, it was not clearly defined whether the TRPM2 channel is important in EtOH-induced microglial cell death. In the current study, using BV2 microglial cells, we firstly demonstrated that the TRPM2 channel is expressed in BV2 microglial cells (Figure 1) and mediates $\mathrm{H}_{2} \mathrm{O}_{2}$-induced cell death (Figure 2a,b). These observations are highly consistent with what we have recently reported in primary microglial cells [25]. Like exposure to $\mathrm{H}_{2} \mathrm{O}_{2}$, we showed that exposure to EtOH evoked significant microglial cell death (Figure 3a,b). Furthermore, similar to $\mathrm{H}_{2} \mathrm{O}_{2}$-induced cell death (Figure 2c), EtOH-induced cell death was strongly inhibited by treatment with 2-APB and, to a lesser extent, ACA, two structurally different TRPM2 channel inhibitors (Figure 3c,d). These results, together, support a crucial role of the TRPM2 channel in mediating EtOH-induced microglial cell death. It is known that exposure to alcohol leads to oxidative stress and activation of PARP [8-10] and, as introduced earlier, PARP activation is the major signaling mechanism for oxidative stress-induced TRPM2 channel activation, including in microglial cells [25-29,31-33]. As described in our recent study examining cell death induced by ROS or $\mathrm{Zn}^{2+}$ in primary microglial cells [25], and in this study showing $\mathrm{H}_{2} \mathrm{O}_{2}$-induced cell death in BV2 microglial cells (Figure 2e-h), EtOH-induced microglial cell death was remarkably attenuated by treatment with PJ34 and DPQ, two structurally different PARP inhibitors (Figure 3), supporting that PARP activation is 
critical in EtOH-induced TRPM2-mediated microglial cell death. Taken together, these results suggest that exposure to EtOH induces microglial cell death via PARP-dependent TRPM2 channel activation.

In the current study, we also investigated the signaling mechanisms by which EtOH stimulates activation of PARP and the TRPM2 channel, which leads to subsequent cell death in microglial cells. ROS production is one of the common events involved in mediating TRPM2 channel activation [26-29]. It has been well documented that $\mathrm{EtOH}$ can stimulate ROS production [9] via induction of NOX [11]. Consistent with this notion, we showed that exposure to high concentrations of EtOH induced a significant increase in ROS production in microglial cells (Figure 4a,b) and, furthermore, that EtOH-induced microglial cell death was prevented by treatment with PKC and NOX inhibitors (Figure $4 \mathrm{c}-\mathrm{f}$ ), consistent with the notion that PKC/NOX-mediated ROS production acts as an upstream mechanism in mediating EtOH-induced TRPM2 channel activation and microglial cell death.

To summarize, the results presented in this study suggest that exposure to $\mathrm{EtOH}$ at pathologically relevant concentrations results in microglial cell death via induction of NOX-mediated ROS generation and subsequent activation of PARP and the TRPM2 channel. As illustrated in Figure 5, such a mechanism offers novel and potentially important insights into alcohol-induced brain pathologies. Nevertheless, it is evident that more investigations are warranted to explore this new mechanism. In microglial cells, the TRPM2 channel is mainly expressed on the cell surface and plays a key role in mediating ROS-induced $\mathrm{Ca}^{2+}$ influx [32,33], which is endorsed with the results we obtained in BV2 microglial cells (Figure 1c,d), but the role of such TRPM2-mediated $\mathrm{Ca}^{2+}$ signalling in EtOH-induced microglial cell death remains to be ascertained. We have recently shown that $\mathrm{H}_{2} \mathrm{O}_{2} / \mathrm{Zn}^{2+}$-induced cell death in primary microglial cells occurs predominantly via necrosis [25], and it is interesting to establish whether such a mechanism also underpins EtOH-induced microglial cell death. Most importantly, in vivo studies using rodent models of alcohol-induced brain pathologies in combination with pharmacological or genetic interventions are needed to testify the significance of the finding reported in this study.

\section{Conclusions}

Our study shows that exposure to EtOH induces microglial cell death via the NOX/ROS/ PARP/TRPM2 signaling pathway. Our finding provides novel insights into the mechanisms potentially underlying alcohol-induced brain pathologies and suggests targeting the TRPM2 channel as an avenue to treat such conditions.

Author Contributions: Conceptualization, S.A.S.M. and L.-H.J.; methodology, S.A.S.M. and L.-H.J.; software, S.A.S.M., M.S.A.S., Y.H. and L.-H.J.; validation, S.A.S.M. and L.-H.J.; formal analysis, S.A.S.M., and M.S.A.S.; investigation, S.A.S.M., M.S.A.S., S.R., I.N.H. and M.H.I.D.; resources, S.A.S.M., L.-H.J., N.B.A., M.E.K. and S.A.; data curation, S.A.S.M. and L.-H.J.; writing—original draft preparation, S.A.S.M. and M.S.A.S.; writing一review and editing, S.A.S.M., M.S.A.S., S.R. and L.-H.J.; visualization, S.A.S.M., L.-H.J. and M.S.A.S.; supervision, S.A.S.M. and L.-H.J.; project administration, S.A.S.M. and L.-H.J.; funding acquisition, S.A.S.M. and L.-H.J. All authors have read and agreed to the published version of the manuscript.

Funding: This research was funded in part by an IPM grant (GP-IPM: 979600) from Universiti Putra Malaysia and a Malaysian Governmental PhD Scholarship (S.A.S.M.) and a grant from the Wellcome Trust (088170) (L.-H.J.).

Conflicts of Interest: The authors declare no conflict of interest.

\section{References}

1. National Institute on Alcohol And Alcoholism (NIAAA). Alcohol Use Disorder. Available online: https: //www.niaaa.nih.gov/alcohol-health/overview-alcohol-consumption/alcohol-use-disorders (accessed on 6 May 2019).

2. Paton, A. Alcohol in the body. BMJ 2005, 330, 85-87. [CrossRef]

3. Osna, N.A.; Donohue, T.M., Jr.; Kharbanda, K.K. Alcoholic liver disease: Pathogenesis and current management. Alcohol Res. 2017, 38, 147-161.

4. Piano, M.R. Alcohol's effects on the cardiovascular system. Alcohol Res. 2017, 38, 219-241. 
5. Ahmadi, A.; Pearlson, G.D.; Meda, S.A.; Dager, A.; Potenza, M.N.; Rosen, R.; Austad, C.S.; Raskin, S.A.; Fallahi, C.R.; Tennen, H.; et al. Influence of alcohol use on neural response to Go/No-Go task in college drinkers. Neuropsychopharmacology 2013, 38, 2197-2208. [CrossRef]

6. de la Monte, S.M.; Kril, J.J. Human alcohol-related neuropathology. Acta Neuropathol. 2014, 127, 71-90. [CrossRef]

7. Warden, A.S.; Wolfe, S.A.; Khom, S.; Varodayan, F.P.; Patel, R.R.; Steinman, M.Q.; Bajo, M.; Montgomery, S.E.; Vlkolinsky, R.; Nadav, T.; et al. Microglia control escalation of drinking in alcohol-dependent mice: Genomic and synaptic drivers. Biol. Psychiatry 2020. [CrossRef]

8. Gavin, D.P.; Kusumo, H.; Sharma, R.P.; Guizzetti, M. Ethanol-induced changes in poly (ADP-ribose) polymerase and neuronal developmental gene expression. Neuropharmacology 2016, 110, 287-296. [CrossRef]

9. Quintanilla, M.E.; Ezquer, F.; Morales, P.; Ezquer, M.; Olivares, B.; Santapau, D.; Herrera-Marschitz, M.; Israel., Y. N-acetylcysteine and acetylsalicylic acid inhibit alcohol consumption by different mechanisms: Combined protection. Front. Behav. Neurosci. 2020, 14, 122. [CrossRef]

10. Vallerini, G.P.; Cheng, Y.H.; Chase, K.A.; Sharma, R.P.; Kusumo, H.; Khakhkhar, S.; Feinstein, D.L.; Guizzetti, M.; Gavin, D.P. Modulation of poly ADP-ribose polymerase (PARP) levels and activity by alcohol binge-like drinking in male mice. Neuroscience 2020, 448, 1-13. [CrossRef]

11. Kamal, H.; Tan, G.C.; Ibrahim, S.F.; Shaikh, M.F.; Mohamed, I.N.; Mohamed, R.M.P.; Hamid, A.A.; Ugusman, A.; Kumar, J. Alcohol use disorder, neurodegeneration, Alzheimer's and Parkinson's disease: Interplay between oxidative stress, neuroimmune response and excitotoxicity. Front. Cell Neurosci. 2020, 14, 1-15. [CrossRef]

12. Goodwani, S.; Saternos, H.; Alasmari, F.; Sari, Y. Metabotropic and ionotropic glutamate receptors as potential targets for the treatment of alcohol use disorder. Neurosci. Biobehav. Rev. 2017, 77, 14-31. [CrossRef] [PubMed]

13. Li, Q.; Barres, B.A. Microglia and macrophages in brain homeostasis and disease. Nat. Rev. Immunol. 2018, 18, 225-242. [CrossRef]

14. Colonna, M.; Butovsky, O. Microglia function in the central nervous system during health and neurodegeneration. Annu. Rev. Immunol. 2017, 35, 441-468. [CrossRef]

15. Wolf, S.A.; Boddeke, H.W.; Kettenmann, H. Microglia in physiology and disease. Annu. Rev. Physiol. 2017, 79, 619-643. [CrossRef]

16. Toyama, H.; Hatano, K.; Suzuki, H.; Ichise, M.; Momosaki, S.; Kudo, G.; Ito, F.; Kato, T.; Yamaguchi, H.; Katada, K.; et al. In vivo imaging of microglial activation using a peripheral benzodiazepine receptor ligand: [11C]PK-11195 and animal PET following ethanol injury in rat striatum. Ann. Nucl. Med. 2008, 22, 417-424. [CrossRef]

17. Fernandez-Lizarbe, S.; Pascual, M.; Guerri, C. Critical role of TLR4 response in the activation of microglia induced by ethanol. J. Immunol. 2009, 183, 4733-4744. [CrossRef]

18. Yang, J.Y.; Xue, X.; Tian, H.; Wang, X.X.; Dong, Y.X.; Wang, F.; Zhao, Y.N.; Yao, X.C.; Cui, W.; Wu, C.F. Role of microglia in ethanol-induced neurodegenerative disease: Pathological and behavioral dysfunction at different developmental stages. Pharmacol. Ther. 2014, 144, 321-337. [CrossRef]

19. Ahlers, K.E.; Karaçay, B.; Fuller, L.; Bonthius, D.J.; Dailey, M.E. Transient activation of microglia following acute alcohol exposure in developing mouse neocortex is primarily driven by BAX-dependent neurodegeneration. Glia 2015, 63, 1694-1713. [CrossRef]

20. Walter, T.J.; Crews, F.T. Microglial depletion alters the brain neuroimmune response to acute binge ethanol withdrawal. J. Neuroinflamm. 2017, 14, 86. [CrossRef]

21. Walter, T.J.; Vetreno, R.P.; Crews, F.T. Alcohol and stress activation of microglia and neurons: Brain regional effects. Alcohol. Clin. Exp. Res. 2017, 41, 2066-2081. [CrossRef]

22. Erickson, E.K.; Blednov, Y.A.; Harris, R.A.; Mayfield, R.D. Glial gene networks associated with alcohol dependence. Sci. Rep. 2019, 9, 10949. [CrossRef] [PubMed]

23. Warden, A.S.; Triplett, T.A.; Lyu, A.; Grantham, E.K.; Azzam, M.M.; DaCosta, A.; Harris, R.A. Microglia depletion and alcohol: Transcriptome and behavioral profiles. Addict. Biol. 2020, e12889. [CrossRef] [PubMed]

24. Freire, D.; Reyes, R.E.; Baghram, A.; Davies, D.L.; Asatryan, L. P2X7 receptor antagonist A804598 inhibits inflammation in brain and liver in C57BL/6J mice exposed to chronic ethanol and high fat diet. J. Neuroimmune Pharmacol. 2019, 14, 263-277. [CrossRef] [PubMed] 
25. Mortadza, S.S.; Sim, J.A.; Stacey, M.; Jiang, L.H. Signalling mechanisms mediating $\mathrm{Zn}^{2+}$-induced TRPM2 channel activation and cell death in microglial cells. Sci. Rep. 2017, 7, 45032. [CrossRef]

26. Yildizhan, Y.; Naziroglu, M. Glutathione depletion and parkinsonian neurotoxin $\mathrm{MPP}^{+}$-induced TRPM2 channel activation play central roles in oxidative cytotoxicity and inflammation in microglia. Mol. Neurobiol. 2020, 57, 3508-3525. [CrossRef]

27. Jiang, L.H.; Yang, W.; Zou, J.; Beech, D.J. TRPM2 channel properties, functions and therapeutic potentials. Expert Opin. Ther. Targets 2010, 14, 973-988. [CrossRef]

28. Jiang, L.H.; Li, X.; Syed Mortadza, S.A.; Lovatt, M.; Yang, W. The TRPM2 channel nexus from oxidative damage to Alzheimer's pathologies: An emerging novel intervention target for age-related dementia. Ageing Res. Rev. 2018, 47, 67-79. [CrossRef]

29. Malko, P.; Jiang, L.H. TRPM2 channel-mediated cell death: An important mechanism linking oxidative stress-inducing pathological factors to associated pathological conditions. Redox Biol. 2020, 37, 101755. [CrossRef]

30. Kraft, R.; Grimm, C.; Grosse, K.; Hoffmann, A.; Sauerbruch, S.; Kettenmann, H.; Harteneck, C. Hydrogen peroxide and ADP-ribose induce TRPM2-mediated calcium influx and cation currents in microglia. Am. J. Physiol. Cell Physiol. 2004, 286, C129-C137. [CrossRef]

31. Alawieyah, S.M.S.; Sim, J.A.; Neubrand, V.E.; Jiang, L.H. A critical role of TRPM2 channel in A $\beta_{42}$-induced microglial activation and generation of tumor necrosis factor- $\alpha$. Glia 2018, 66, 562-575. [CrossRef]

32. Mortadza, S.A.S.; Wang, L.; Li, D.; Jiang, L.H. TRPM2 channel-mediated ROS-sensitive Ca ${ }^{2+}$ signaling mechanisms in immune cells. Front. Immunol. 2015, 6, 407. [CrossRef] [PubMed]

33. Malko, P.; Mortadza, S.A.S.; McWilliam, J.; Jiang, L.H. TRPM2 channel in microglia as a new player in neuroinflammation associated with a spectrum of central nervous system pathologies. Front. Pharmacol. 2019, 10, 239. [CrossRef] [PubMed]

34. Asatryan, L.; Ostrovskaya, O.; Lieu, D.; Davies, D.L. Ethanol differentially modulates P2X4 and P2X7 receptor activity and function in BV2 microglial cells. Neuropharmacology 2018, 128, 11-21. [CrossRef] [PubMed]

35. Lawrimore, C.J.; Coleman, L.G.; Zou, J.; Crews, F.T. Ethanol induction of innate immune signals across BV2 microglia and SH-SY5Y neuroblastoma involves induction of IL-4 and IL-13. Brain Sci. 2019, 9, 228. [CrossRef]

36. Zou, J.; Ainscough, J.F.; Yang, W.; Sedo, A.; Yu, S.P.; Mei, Z.Z.; Jiang, L.H. A differential role of macrophage TRPM2 channels in $\mathrm{Ca}^{2+}$ signaling and cell death in early responses to $\mathrm{H}_{2} \mathrm{O}_{2}$. Am. J. Physiol. Cell Physiol. 2013, 305, C61-C69. [CrossRef]

37. Li, C.; Peoples, R.W.; Weight, F.F. Ethanol-induced inhibition of a neuronal P2X purinoceptor by an allosteric mechanism. Br. J. Pharmacol. 1998, 123, 1-3. [CrossRef]

38. Frye, G.D.; Fincher, A. Sustained ethanol inhibition of native AMPA receptors on medial septum/diagonal band (MS/DB) neurons. Br. J. Pharmacol. 2000, 129, 87-94. [CrossRef]

39. Zhao, Y.; Ren, H.; Peoples, R.W. Intersubunit interactions at putative sites of ethanol action in the M3 and M4 domains of the NMDA receptor GluN1 and GluN2B subunits. Br. J. Pharmacol. 2016, 173, 1950-1965. [CrossRef]

40. Noh, K.M.; Koh, J.Y. Induction and activation by zinc of NADPH oxidase in cultured cortical neurons and astrocytes. J. Neurosci. 2000, 20, RC111. [CrossRef]

Publisher's Note: MDPI stays neutral with regard to jurisdictional claims in published maps and institutional affiliations.

(C) 2020 by the authors. Licensee MDPI, Basel, Switzerland. This article is an open access article distributed under the terms and conditions of the Creative Commons Attribution (CC BY) license (http://creativecommons.org/licenses/by/4.0/). 